\title{
Early lung growth and chronic airflow obstruction
}

Over the last 30 years the hypothesis that chronic airflow obstruction has its origins in early life has stimulated much interest. ${ }^{1-5}$ Studies have generally focused on lower respiratory tract infection and other influences which act in infancy and early childhood..$^{6-9}$ Recent findings, however, suggest that the foundations of chronic airflow obstruction may be laid in utero. A study in Hertfordshire, UK, of men over 60 years of age showed that those who weighed less at birth had a lower $\mathrm{FEV}_{1}$, after adjusting for current height. It was suggested that this association reflected suboptimal development of the lungs as a result of fetal undernutrition. ${ }^{10}$

Animal experiments have shown that the structure and physiology of organs and tissues may be permanently altered by undernutrition or other influences which affect development during sensitive periods in early life. This phenomenon is known as "programming." One of the best examples is the lifelong effect on sexual physiology of transient early exposure to sex hormones. ${ }^{11}$ Tissues are sensitive to programming during periods of rapid cell replication in early development. This occurs at different times in different tissues. The consequences of undernutrition during fetal and early postnatal life therefore depend upon its timing as well as its nature. ${ }^{1213}$ Humans complete relatively more growth in utero than many other mammals, and hence are more vulnerable to prenatal undernutrition. ${ }^{14}$

This discussion will focus on the long term consequences of altered lung structure during early growth as a result of influences such as undernutrition in fetal life. Relations between the early life environment and immunological and physiological pathways involving, for example, IgE and bronchial hyperreactivity, may also be important in the development of chronic airflow obstruction, but will not be discussed here.

\section{Lung growth in animals}

In experimental animals, including the rat and guinea pig, the fetal environment can be manipulated in different ways to cause pulmonary hypoplasia, as defined by a reduction in the lung weight/body weight ratio and in total lung DNA. Manipulations include maternal calorie deprivation, ${ }^{15-17}$ hypoxia, ${ }^{18}$ and exposure to cigarette smoke. ${ }^{19}{ }^{20}$ In the rat interference with lung growth may permanently alter alveolar morphology and parenchymal recoil. Deprivation of calories, protein, or copper leads to a reduction in elastin and collagen in the lung, enlargement of air spaces, and a reduction in elastic recoil in a way that resembles human emphysema. ${ }^{21-25}$ Similar changes can be induced by administration of $\beta$-aminopropionitrile which, like copper deficiency, inhibits the enzyme lysyl oxidase. This enzyme is essential for normal crosslinking of collagen and elastin and hence normal formation of alveoli. ${ }^{26}$

Animal studies have shown that the timing of adverse influences determines whether effects on lung growth are permanent. In guinea pigs, prenatal starvation alters alveolar morphology permanently, but the changes induced by postnatal starvation are reversible. ${ }^{27} 28$ In rats, alveolar changes are more likely to be permanent if protein or calorie restriction occurs in early postnatal life during a critical period of elastin synthesis, ${ }^{23}$ but changes induced after weaning may be reversible. ${ }^{228}$ There are major differences between these two species in the maturity of the lung at birth. ${ }^{28}$ Alveolar development is largely completed prenatally in the guinea pig. ${ }^{29}$ In the rat, however, alveolar growth is mainly postnatal, ${ }^{30}$ with a critical period of rapid cell replication between days 4 and $13 .^{31}$

\section{Lung growth in humans}

In humans, airway division down to the level of the terminal bronchioles is completed by the 16th week of gestation. ${ }^{32}$ Wigglesworth and Desai ${ }^{33}$ have shown that this is followed by a period of rapid lung growth; between 17 and 20 weeks the lung cell population doubles and at 20 weeks the lungs are twice as large relative to body weight as at term. Alveoli can be detected as early as 30 weeks in the fetus. ${ }^{3435}$ Initial studies of small numbers of infants suggested that about $10 \%$ of the adult number of alveoli are present at birth. ${ }^{3637}$ More recent studies of larger numbers of infants have suggested that, although there is a wide range in the number of alveoli present at birth, the average number is much higher than previously thought, and possibly as high as $50 \%$ of the adult number..$^{34} 38$ Postnatally, multiplication slows and is nearly completed by two years of age, ${ }^{38}$ but during this period there is a rapid increase in alveolar size and complexity. Of the adult alveolar surface area, $95 \%$ is formed postnatally. ${ }^{34}$

How commonly is lung growth impaired in utero? At postmortem examination lung hypoplasia is defined using threshold values for a reduction in the ratio of lung to body weight, the total lung DNA content, or the radial alveolar count, based on series of "normal" values. ${ }^{3339}$ In one survey hypoplasia defined in this way was found in $14 \%$ of perinatal postmortem examinations and $27 \%$ of cases of late spontaneous abortion, usually in association with other anomalies such as renal agenesis, diaphragmatic hernia, and oligohydramnios. ${ }^{40}$

What are the functional consequences of lung hypoplasia? Airflow obstruction may develop in children who survive repair of a congenital diaphragmatic hernia. ${ }^{41}$ Helms has recently drawn attention to the increasing evidence for long term consequences of less severe growth retardation in utero. ${ }^{42}$ Epidemiological studies have examined the association between birth weight, as a marker of prenatal lung growth, and lung function in children and adults. Within a group of children who weighed less than $2000 \mathrm{~g}$ at birth, lower birth weight was associated with a lower $\mathrm{FEV}_{1}$, adjusted for height, at the age of 7 years. ${ }^{43}$ Most of the children in that study were premature at birth. A larger study of children aged 5-11 years recently showed that the association between birth weight and $\mathrm{FEV}_{1}$, adjusted for age and height, was independent of gestational age ${ }^{44}$ Among men born 60-70 years ago in Hertfordshire, lower birth weight was associated with a reduced $\mathrm{FEV}_{1}$, adjusted for age and height, with mean $\mathrm{FEV}_{1}$ falling by $60 \mathrm{ml}$ with every pound decrease in birth weight. This relation was independent of social class and smoking habits. Furthermore, death rates from chronic airflow obstruction rose with decreasing birth weight and weight at one year of age. There was an approximately fourfold difference in the standardised mortality ratio for chronic airflow obstruction between men with the lowest and the highest weights at birth and one year. ${ }^{10}$

The graded nature of the findings in the Hertfordshire 
study across the entire distribution of early weights suggests that even slight impairment of lung growth may impair lung function in later life. What are likely to be the most important influences affecting fetal lung growth? Expiratory flows are reduced in infants born to mothers who smoke during pregnancy, ${ }^{45}$ but the relation between birth weight and $\mathrm{FEV}_{1}$ in children persists after adjustment for maternal smoking. ${ }^{44}$ Similarly, the findings in the Hertfordshire study are unlikely to be explained by maternal smoking as the men were born at a time when few women smoked. Fetal undernutrition may therefore be a major determinant of impaired lung growth in utero, and the main explanation for the association found between birth weight and $\mathrm{FEV}_{1}$ in children and adults.

\section{Control of lung growth}

Physical influences appear to be important in the regulation of lung growth. ${ }^{46}$ One requirement for normal growth is adequate intrathoracic space. When abdominal contents encroach upon this space through an experimental diaphragmatic hernia, it leads to pulmonary hypoplasia. ${ }^{47}$ In humans, congenital diaphragmatic hernia is associated with a reduction in the number of airway branches indicating retardation of lung growth which begins in early gestation. ${ }^{4849}$ Intrathoracic space can also be restricted by abnormal chest wall growth. This can occur as a result of chest compression in association with oligohydramnios ${ }^{5051}$ or as a result of skeletal deformity as in kyphoscoliosis. ${ }^{5253}$ Thurlbeck has suggested that the growing chest wall provides a "stretch" stimulus for growth of the underlying lung. ${ }^{51}$

Distensive forces from within the lung also appear to be important and are provided by fetal breathing movement and lung fluid. Fetal breathing depends on normal diaphragmatic function. If this is abolished by spinal cord or phrenic nerve section, lung growth is impaired. ${ }^{5455} \mathrm{Pul}-$ monary hypoplasia has been linked to an absence of fetal breathing in humans. ${ }^{56}$

In animals reducing the volume of amniotic fluid ${ }^{505758}$ or draining lung fluid from the airways ${ }^{5960}$ leads to pulmonary hypoplasia. Similarly, in humans oligohydramnios is associated with lung hypoplasia and narrow airways. ${ }^{4061}$ The earlier the onset of the reduction in amniotic fluid volume, the more severe the degree of lung hypoplasia. ${ }^{6263}$ Hence, an adequate amount of lung fluid within the airways appears to be necessary for optimal airway growth. A recent study showed that growth factors are involved in human airway growth ${ }^{64}$ and these may be transported by lung fluid. ${ }^{40}$

Hypoplastic lungs may also be immature ${ }^{51}$ and physical influences such as fetal breathing ${ }^{55}$ and amniotic fluid volume $^{61}$ may be important in lung maturation. However, hormones appear to play the major part. $^{65}$ The most studied aspect of maturity is type 2 cell surfactant production. ${ }^{51}$ Surfactant production is stimulated by glucocorticoids and thyroid hormone and inhibited by testosterone. Hence, male human fetuses lag behind females by 1-2 weeks with respect to lung maturation and are more at risk of respiratory distress syndrome. ${ }^{65}$

\section{Disproportionate lung growth}

We know from the animal studies by McCance and Widdowson ${ }^{66}$ that the timing of undernutrition determines the pattern of growth retardation. Early undernutrition produces small but normally proportioned animals. Later undernutrition leads to selective organ damage and, as a result, lung growth is diminished more than somatic growth. Babies who have experienced undernutrition in later gestation therefore have small lungs for their body size. Failure of airway growth to catch up with somatic growth would lead to airways which were small for adult height. This pattern of disproportionate growth could explain the association between birth weight and height adjusted $\mathrm{FEV}_{1}$ found in children and adults. ${ }^{1044}$

Green proposed that disproportionate or "dysanaptic" growth may occur between the airways and parenchyma and that this may explain the substantial variability in maximum expiratory flows between individuals. ${ }^{67}$

Certain environmental influences may impair airway growth or enhance alveolar growth, depending on their nature and timing, and this could lead to airflow obstruction as indicated by a reduction in $\mathrm{FEV}_{1} / \mathrm{FVC}$. For example, in animals alveolar growth may be stimulated by hypoxia leading to an increase in vital capacity; this also appears to occur in humans born at altitude. ${ }^{68}$ Mid gestation is likely to be a particularly vulnerable time for airway growth in humans. Although there are no morphological data, the doubling in lung DNA between 17 and 20 weeks, ${ }^{33}$ which occurs before the first alveoli are apparent, ${ }^{35}$ suggests that airway growth is rapid at this time. Undernutrition and hypoxia in mid and late gestation may therefore lead to a disproportionate pattern of lung growth resulting in airways which are narrow in relation to parenchymal size. Subsequent failure of airway growth to catch up with respect to parenchymal growth in childhood would result in a lower $\mathrm{FEV}_{1} / \mathrm{FVC}$ ratio as an adult.

What is the evidence to suggest that small airways at birth remain small through to adulthood? There are no anatomical data on airway growth in humans but airway size may be inferred from physiological measures of flow.$^{69} 70$ Longitudinal studies of lung function suggest that "tracking" of airway growth, without catch-up, does occur through childhood. ${ }^{71}$ Furthermore, the trajectory of growth appears to be determined by one year of age. ${ }^{72}$

\section{Lower respiratory tract infection, lung growth,} and chronic airflow obstruction

A geographical study found that infant mortality from bronchitis and pneumonia 50 years ago was strongly correlated with current adult mortality from chronic airflow obstruction. This finding was consistent with the hypothesis that lower respiratory tract infection in infancy may be important in the aetiology of chronic airflow obstruction. ${ }^{6}$ Studies which have addressed the hypothesis in individuals have been difficult to interpret. A major limitation is that subjects have not been followed from infancy to an age when clinical chronic airflow obstruction develops, ${ }^{3}$ and adult recall of childhood illness is likely to be inaccurate and biased. ${ }^{73}$ Nevertheless, retrospective follow up studies of infants with bronchiolitis ${ }^{78}$ and a prospective study of a national sample of men and women in the $\mathrm{UK}^{9}$ have found an association between lower respiratory tract infection in the first few years of life and a reduction in subsequent lung function.

Two recent studies have provided further evidence for a link between symptomatic lower respiratory tract infection in early childhood and chronic airflow obstruction in late adult life. In these studies information about symptomatic lower respiratory tract infection in early childhood, recorded at the time, was related to the lung function of men aged 59-74 years living in Hertfordshire and Derbyshire. The Hertfordshire study showed that bronchitis and pneumonia in infancy, but not in later childhood, was associated with a lower mean $\mathrm{FEV}_{1}$, adjusted for age and height, in men aged 59-67 years. ${ }^{10}$ In the Derbyshire study pneumonia under two years of age was associated with a large reduction in mean $\mathrm{FEV}_{1}$, adjusted for age and height, 
in men aged 67-74 years. The deficit in $\mathrm{FEV}_{1}$ of 0.651 was approximately twice the reduction associated with lifelong smoking. ${ }^{74}$ In both studies the findings were independent of smoking and social class.

The findings in the Hertfordshire and Derbyshire studies are consistent with a causal link between lower respiratory tract infection in early childhood and chronic airflow obstruction in adult life. Taussig has proposed an alternative explanation, namely that lower respiratory tract infection plays no part in aetiology but merely identifies individuals in whom airway size is reduced in early life and who are therefore more likely to exhibit clinical symptoms if infection occurs. ${ }^{75}$ Thus symptomatic lower respiratory tract infection may simply identify the individual with small airways who is more prone to continuing problems throughout life. Prospective studies in which lung function has been measured soon after birth ${ }^{76}$ may help to disentangle the relations between airway growth in utero, lower respiratory tract infection in infancy, and lung function in adult life. It may be the case that respiratory viruses are only capable of causing permanent structural damage if there is pre-existing impairment of local lung defences or systemic immunity, or if the infection is severe. ${ }^{77}$

\section{Sex differences in early lung growth}

In recent years it has been recognised that there are differences in the pattern of early lung growth between boys and girls. Airway growth tends to lag behind parenchymal growth in boys in early life. ${ }^{70}$ Boys have a larger lung volume than girls of a similar age and stature, ${ }^{38}$ but girls appear to have shorter wider airways for their lung volume. ${ }^{78}$ In the Hertfordshire study the associations between birth weight and $F E V_{1}$ and between weight at one year and chronic airflow obstruction mortality found in men were weaker in women (unpublished). Differences in early growth patterns may explain this.

Similarly, the associations between lower respiratory tract infection in early childhood and $\mathrm{FEV}_{1}$ in men were weaker in women in Hertfordshire (unpublished) and in Derbyshire. ${ }^{74}$ This is consistent with a study of children in which pneumonia in early childhood was related to impaired lung function in boys but not in girls. ${ }^{79}$ It is recognised that boys suffer more severe lower respiratory tract infection than girls in infancy and are more likely to be hospitalised with bronchiolitis. ${ }^{80} 81$ This has been partly attributed to the smaller airway size in boys in early life. ${ }^{69}$

\section{Conclusions and future agenda}

In the past, discussion of the natural history of chronic airflow obstruction has tended to focus on the rate of decline of adult lung function. ${ }^{82}$ The Hertfordshire findings, however, show that clinical chronic airflow obstruction may also develop through impaired lung growth in early life. ${ }^{10}$ Influences which determine the rate of functional decline, of which smoking is the most important, add to the effects of poor early growth. A moderate smoker who failed to attain maximal lung function potential as a young adult may develop chronic airflow obstruction at the same age as a heavy smoker who achieved maximal lung growth. ${ }^{3}$ Green proposed that the susceptibility to smoking damage may be determined by the pattern of lung growth and structure. ${ }^{67}$ The Hertfordshire findings suggest that the effects of poor growth and smoking on lung function are additive and not synergistic, although measures of early weight may be poor indicators of lung growth. To test this more rigorously it will be necessary to relate early growth to the longitudinal rate of decline in $\mathrm{FEV}_{1}$ in smokers.

There is clear evidence from animals that undernutrition during critical periods of lung growth has permanent effects on lung structure. This may be the most likely explanation for the association between poor growth in utero and in infancy and impaired adult lung function, ${ }^{10}$ but at present there are no data on undernutrition and lung growth in humans. ${ }^{28}$ It would be of interest to investigate this in developing countries where severe restriction of calories and protein in early life is common.

Could undernutrition affect different pulmonary structures depending on its nature and timing, and hence lead to different clinical patterns of chronic airflow obstruction? We have little insight into why some subjects with chronic airflow obstruction are "pink puffers" and others are "blue bloaters." Previous thinking about the pathogenesis of emphysema in humans has been dominated by a destructive model involving protease-antiprotease balance, ${ }^{83}$ but it has been suggested that a "developmental" model of emphysema, as produced in animals, may be relevant in humans. ${ }^{25}$ If so, it may be useful in future epidemiological studies to go beyond measurement of $\mathrm{FEV}_{1}$ and to subclassify subjects with chronic airflow obstruction who have emphysema.

It is 20 years since Green proposed that the pattern of fetal lung growth may influence the development of chronic airflow obstruction. ${ }^{67}$ Recent epidemiological findings support this and indicate the importance of learning more about early lung growth.

Reprint requests to: Dr DJP Barker.

MRC Environmental Epidemiology Unit, Southampton General Hospital, Southampton SO9 $4 X Y$,

$U K$

SO SHAHEEN DJP BARKER

1 Reid DD. The beginnings of bronchitis. Proc $R$ Soc Med 1969;62:311-6. 2 Holland WW. Beginnings of bronchitis. Thorax 1982;37:401-3.

3 Samet JM, Tager IB, Speizer FE. The relationship between respiratory illness in childhood and chronic airflow obstruction in adulthood. Am Rev Respir Dis 1983;127:508-23.

4 Phelan PD. Does adult chronic obstructive lung disease really begin in childhood? Br $\mathcal{F}$ Dis Chest 1984;78:1-9.

5 Strachan DP. Do chesty children become chesty adults? Arch Dis Child 1990;65:161-2.

6 Barker DJP, Osmond C. Childhood respiratory infection and adult chronic bronchitis in England and Wales. $B M \mathcal{F}$ 1986;293:1271-5.

7 Sims DG, Downham MAPS, Gardner PS, Webb JKG, Weightman D. Study of 8 year-old children with a history of respiratory syncytial virus bronchiolitis in infancy. $B M \mathcal{F} 1978 ; 1: 11-4$.

8 Pullan CR, Hey EN. Wheezing, asthma and pulmonary dysfunction 10 years after infection with respiratory syncytial virus in infancy. $B M \mathcal{J}$ 1982;284:1665-9.

9 Mann SL, Wadsworth MEJ, Colley JRT. Accumulation of factors influencing respiratory illness in members of a national birth cohort and their offspring. I Epidemiol Community Health 1992;46:286-92.

10 Barker DJP, Godfrey KM, Fall C, Osmond C, Winter PD, Shaheen SO Relation of birth weight and childhood respiratory infection to adult lung function and death from chronic obstructive airways disease. $B M \mathcal{J}$ 1991;303:671-5.

11 Barraclough CA. Production of anovulatory, sterile rats by single injections of testosterone propionate. Endocrinology 1961;68:62-7.

12 Winick $M$, Noble $A$. Cellular response in rats during malnutrition at various ages. 7 Nutr 1966;89:300-6.

13 Widdowson EM, McCance RA. A review: new thoughts on growth. Pediatr Res 1975;9:154-6.

14 Widdowson EM. Intra-uterine growth retardation in the pig. Biol Neonate 1971;19:329-40.

15 Lechner AJ, Winston DC, Bauman JE. Lung mechanisms, cellularity and surfactant after prenatal starvation in guinea pigs. $\mathcal{f}$ Appl Physiol 1986;60:1610-4

16 Goswami T, Vu M-L, Srivastava U. Quantitative changes in DNA, RNA and protein content of the various organs of the young of undernourished female rats. $f$ Nutr $1974 ; 104: 1257-64$.

17 Faridy EE. Effect of maternal malnutrition on surface activity of fetal lungs in rats. F Appl Physiol 1975;39:535-40.

18 Faridy EE, Sanii MR, Thliveris JA. Fetal lung growth: influence of maternal hypoxia and hyperoxia in rats. Respir Physiol 1988;73:225-42.

19 Collins MH, Moessinger AC, Kleinerman J, Bassi J, Rosso P, Collins AM, et al. Fetal lung hypoplasia associated with maternal smoking: a morphoet al. Fetal lung hypoplasia associated with matric analysis. Pediatr Res 1985;19:408-12.

20 Bassi JA, Rosso P, Moessinger AC, Blanc WA, James LS. Fetal growth retardation due to maternal tobacco smoke exposure in the rat. Pediatr Res $1984 ; 18: 127-30$.

21 Das RM. The effects of intermittent starvation on lung development in suckling rats. Am $\mathcal{F}$ Pathol 1984;117:326-32. 
22 Sahebjami H, MacGee J. Effects of starvation on lung mechanics and biochemistry in young and old rats. $\mathcal{F}$ Appl Physiol 1985;58:778-84.

23 Kalenga $M$, Eeckhout $Y$. Effects of protein deprivation from the neonatal period on lung collagen and elastin in the rat. Pediatr Res 1989;26:125-7.

24 Matsui R, Thurlbeck WM, Fujita Y, Yu SY, Kida K. Connective tissue, mechanical and morphometric changes in the lungs of weanling rats fed a low protein diet. Pediatr Pulmonol 1989;7:159-66.

25 O'Dell BL, Kilburn KH, McKenzie WN, Thurston RJ. The lung of the copper-deficient rat. Am $\mathcal{F}$ Pathol 1978;91:413-32.

$26 \mathrm{Kida} \mathrm{K}$, Thurlbeck WM. The effects of $\beta$-aminoproprionitrile on the growing rat lung. Am $\mathcal{f}$ Pathol 1980;101:693-710.

27 Lechner AJ. Perinatal age determines the severity of retarded lung development induced by starvation. Am Rev Respir Dis 1985;131:638-43.

28 Gaultier C. Malnutrition and lung growth. Pediatr Pulmonol 1991;10:27886.

29 Lechner AJ, Banchero N. Advanced pulmonary development in newborn guinea pigs (Cavia porcellus). Am $\mathcal{f}$ Anat 1982;163:235-46.

30 Burri P, Dbaly J, Weibel ER. The postnatal growth of the rat lung I. Morphometry. Anat Rec 1974;178:711-30.

31 Winick $M$, Noble $A$. Quantitative changes in DNA, RNA and protein during prenatal and postnatal growth in the rat. Dev Biol 1965;12:451-6.

32 Bucher U, Reid L. Development of the intrasegmental tree; the pattern of branching and development of cartilage at various stages of intrauterine life. Thorax 1961;16:207-18.

33 Wigglesworth JS, Desai R. Use of DNA estimation for growth assessment in normal and hypoplastic fetal lungs. Arch Dis Child 1981;56:601-5.

34 Hislop AA, Wigglesworth JS, Desal R. Alveolar development in the human fetus and infant. Early Hum Dev 1986;13:1-11.

35 Langston C, Kida K, Reed M, Thurlbeck WM. Human lung growth in late gestation and in the neonate. Am Rev Respir Dis 1984;129:607-13.

36 Dunnill MS. Post natal growth of the lung. Thorax 1962;17:329-33.

37 Davies G, Reid L. Growth of the alveoli and pulmonary arteries in childhood. Thorax 1970;25:669-81.

38 Thurlbeck WM. Postnatal human lung growth. Thorax 1982;37:564-71.

39 Askenazi SS, Perlman M. Pulmonary hypoplasia: lung weight and radial alveolar count as criteria of diagnosis. Arch Dis Child 1979;54:614-8.

40 Wigglesworth JS, Desai R. Is fetal respiratory function a major determinant of perinatal survival? Lancet 1982;i:264-7.

41 Falconer AR, Brown RA, Helms P, Gordon I, Baron JA. Pulmonary sequelae in survivors of congenital diaphragmatic hernia. Thorax 1990;45:126-9.

42 Helms PJ. Factors affecting lung growth and development. Paediatr Respir 993:1:11-4.

43 Chan KN, Noble-Jamieson CM, Elliman A, Bryan EM, Silverman M. Lung function in children of low birth weight. Arch Dis Child 1989;64:1284-93.

44 Rona RJ, Gulliford MC, Chinn S. Effects of prematurity and intrauterine growth on respiratory health and lung function in childhood. $B M F$ 1993;306:817-20.

45 Hanrahan JP, Tager IB, Segal MR, Tosteson TD, Castile RG, Van Vunakis $\mathrm{H}$, et al. The effect of maternal smoking during pregnancy on early infant lung function. Am Rev Respir Dis 1992;145:1129-35.

46 Kitterman JA. Fetal lung development. $\mathcal{F}$ Dev Physiol 1984;6:67-82.

47 Pringle KC, Turner JW, Schofield JC, Soper RT. Creation and repair of diaphragmatic hernia in the fetal lamb: lung development and morphology. $\mathcal{F}$ Pediatr Surg 1984;19:131-40.

48 Hislop A, Reid L. Persistent hypoplasia of the lung after repair of congenital diaphragmatic hernia. Thorax 1976;31:452-5.

49 Helms $P$, Stocks J. Lung function in infants with congenital pulmonary hypoplasia. I Pediatr 1982;101:918-22.

50 Nakayama DK, Glick PL, Harrison MR, Villa RL, Noall R. Experimental pulmonary hypoplasia due to oligohydramnios and its reversal by relieving thoracic compression. $\mathcal{F}$ Pediatr Surg 1983;18:347-53.

51 Thurlbeck WM. Prematurity and the developing lung. Clin Perinatol 1992;19:497-519.

52 Davies G, Reid L. Effect of scoliosis on growth of alveoli and pulmonary arteries and on right ventricle. Arch Dis Child 1971;46: 623-32.

53 Owange-Iraka JW, Harrison A, Warner JO. Lung function in congenital and idiopathic scoliosis. Eur $\mathcal{f}$ Pediatr 1984;142:198-200.

54 Wigglesworth JS, Desai R. Effects on lung growth of cervical cord section in the rabbit fetus. Early Hum Dev 1979;3:51-65.

55 Nagai A, Thurlbeck WM, Jansen AH, Ioffe S, Chernick V. The effect of chronic biphrenectomy on lung growth and maturation in fetal lambs. $\mathrm{Am}$ Rev Respir Dis 1988;137:167-72.

56 Blott M, Greenough A, Nicolaides KH, Moscoso G, Gibb D, Campbell S. Fetal breathing movements as predictor of favourable pregnancy outcome after oligohydramnios due to membrane rupture in second trimester. Lancet 1987;ii:129-31.
57 Moessinger AC, Bassi GA, Ballantyne G, Collins MH, James LS, Blanc WA. Experimental production of pulmonary hypoplasia following amniocentesis and olighydramnios. Early Hum Dev 1983;8:343-50.

58 Higuchi M, Kato T, Yoshino H, Matsuda K, Gotoh K, Hirano H, et al. The influence of experimentally produced oligohydramnios on lung growth and pulmonary surfactant content in fetal rabbits. $\mathcal{f}$ Dev Physiol 1991;16:223-7.

59 Fisk NM, Parkes MJ, Moore PJ, Haidar A. Wigglesworth J, Hanson MA. Fetal breathing during chronic lung liquid loss leading to pulmonary hypoplasia. Early Hum Dev 1991;27:53-63.

60 Moessinger AC, Harding R, Adamson TM, Singh M, Kiu GT. Role of lung fluid volume in growth and maturation of the fetal sheep lung. $f$ Clin Invest 1990;86:1270-7.

61 Wigglesworth JS, Desai R, Guerrini P. Fetal lung hypoplasia: biochemical and structural variations and their possible significance. Arch Dis Child 1981;56:606-15.

62 Nimrod C, Varela-Gittings F, Machin G, Campbell D, Wesenberg R. The effect of very prolonged membrane rupture on fetal development. $\mathrm{Am} \mathcal{F}$ Obstet Gymecol 1984:148:540-3.

63 Roberts AB, Mitchell JM. Direct ultrasonographic measurements of fetal lung length in normal pregnancies and pregnancies complicated by prolonged rupture of membranes. Am f Obstet Gynecol 1990;163:1560-6.

64 Strandjord TP, Clark JG, Hodson WA, Schmidt RA, Madtes DK. Expression of transforming growth factor- $\alpha$ in mid-gestation human fetal lung. Am $\mathcal{F}$ Respir Cell Mol Biol 1993;8:266-72.

65 Gross I. Regulation of fetal lung maturation. Am f Physiol 1990;259:L33744.

66 McCance RA, Widdowson EM. The determinants of growth and form. Proc $R$ Soc Lond B 1974;185:1-17.

67 Green M, Mead J, Turner JM. Variability of maximum expiratory flowvolume curves. $\mathcal{F}$ Appl Physiol 1974;37:67-74.

68 Brody JS, Vaccaro C. Postnatal formation of alveoli: interstitial events and physiological consequences. Fed Proc 1979;38:215-23.

69 Tepper RS, Morgan WJ, Cota K, Wright A, Taussig LM, GHMA pediatricians. Physiologic growth and development of the lung during the first year of life. Am Rev Respir Dis 1986;134:513-9.

70 Pagtakhan RD, Bjelland JC, Landau LI, Loughlin G, Kaltenborn W, Seeley $\mathrm{G}, e t$ al. Sex differences in growth patterns of the airways and lung parenchyma in children. 7 Appl Physiol 1984;56:1204-10.

71 Dockery DW, Berkey CS, Ware JH, Speizer FE, Ferris BG. Distribution of forced vital capacity and forced expiratory volume in one second in children 6 to 11 years of age. Am Rev Respir Dis 1983;128:405-12.

72 Chan KN, Wong YC, Silverman M. Relationship between infant lung mechanics and childhood lung function in children of very low birthweight. Pediatr Pulmonol 1990;8:74-81.

73 Burrows B, Knudson RJ, Lebowitz MD. The relationship of childhood respiratory illness to adult obstructive airways disease. Am Rev Respir Dis 1977;115:751-60.

74 Shaheen SO, Barker DJP, Shiell AW, Crocker FJ, Wield GA, Holgate ST. The relationship between pneumonia in early childhood and impaired lung function in late adult life. Am $\mathcal{f}$ Respir Crit Care Med 1994;149: (in press).

75 Taussig LM. The conundrum of wheezing and airway hyperreactivity in infancy. Pediatr Pulmonol 1992;13:1-3.

76 Martinez FD, Morgan WJ, Wright AG, Holberg C, Taussig LM. Initial airway function is a risk factor for recurrent wheezing respiratory illnesses during the first three years of life. Am Rev Respir Dis 1991;143:312-6.

77 Becroft DMO. Bronchiolitis obliterans, bronchiectasis and other sequelae of adenovirus type 21 infection in young children. 7 Clin Pathol 1971;24:72-82.

78 Hibbert ME, Couriel JM, Landau LI. Changes in lung, airway and chest wall function in boys and girls between 8 and 12 years. 7 Appl Physiol 1984;57:304-8.

79 Gold DR, Tager IB, Weiss ST, Tosteson TD, Speizer FE. Acute lower respiratory illness in childhood as a predictor of lung function and chronic respiratory symptoms. Am Rev Respir Dis 1989;140:877-84.

80 Glezen WP, Denny FW. Epidemiology of acute lower respiratory disease in children. N Engl f Med 1973;288:498-505.

81 Breese Hall C. Respiratory syncytial virus. In: Feigin RD, Cherry JD, eds. Textbook of pediatric infectious diseases. Philadelphia: WB Saunders, 1981: $1247-66$.

82 Burrows B. Natural history of chronic airflow obstruction. In: Hensley MJ, Saunders NA, eds. Clinical epidemiology of chronic obstructive pulmonary disease. Lung biology in health and disease. Vol 43. New York: Marcel Dekker, 1989;99-107.

83 Janoff A. State of the art. Elastases and emphysema: current assessment of the protease-antiprotease hypothesis. Am Rev Respir Dis 1985;132:41733. 